\title{
Feasibility and safety of robotic-assisted total pancreatectomy: a pilot western series
}

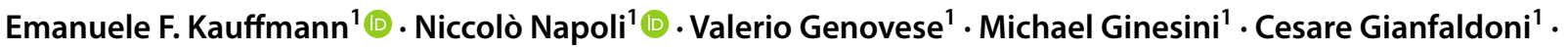 \\ Fabio Vistoli ${ }^{1}$. Gabriella Amorese ${ }^{2} \cdot$ Ugo Boggi $^{1} \mathbb{D}$
}

Received: 13 April 2021 / Accepted: 3 May 2021 / Published online: 19 May 2021

(C) The Author(s) 2021

\begin{abstract}
This study was designed to demonstrate non-inferiority of robot-assisted total pancreatectomy (RATP) to open total pancreatectomy (OPT) based on an intention-to-treat analysis, having occurrence of severe post-operative complications (SPC) as primary study endpoint. The two groups were matched (2:1) by propensity scores. Assuming a rate of SPC of $22.5 \%$ (non-inferiority margin: $15 \% ; \alpha: 0.05 ; \beta: 0.20$; power: $80 \%$ ), a total of 25 patients were required per group. During the study period (October 2008-December 2019), 209 patients received a total pancreatectomy. After application of exclusion and inclusion criteria, matched groups were extracted from an overall cohort of 132 patients (OPT: 107; RATP: 25). Before matching, the two groups were different with respect to prevalence of cardiac disease $(24.3 \%$ versus $4.0 \% ; p=0.03)$, presence of jaundice $(45.8 \%$ versus $12.0 \% ; p=0.002)$, presence of a biliary drainage ( $23.4 \%$ versus $0 ; p=0.004)$, history of weight loss $(28.0 \%$ versus $8.0 \% ; p=0.04)$, and vein involvement $(55.1 \%$ versus $28.0 \%)(p=0.03)$. After matching, the two groups (OTP: 50; RATP: 25) were well balanced. Regarding primary study endpoint, SPC developed in 13 patients (26.0\%) after OTP and in 6 patients $(24.0 \%)$ after RATP $(p=0.85)$. Regarding secondary study endpoints, RATP was associated with longer median operating times [475 (408.8-582.5) versus $585 \mathrm{~min}(525-637.5) p=0.003]$. After a median follow-up time of 23.7 months (10.4-71), overall survival time [22.6 (11.2-81.2) versus NA (27.3-NA) $p=0.006$ ] and cancer-specific survival [22.6 (11.2-NA) versus NA (27.3-NA) $p=0.02]$ were improved in patients undergoing RATP. In carefully selected patients, robot-assisted total pancreatectomy is non-inferior to open total pancreatectomy regarding occurrence of severe post-operative complications.
\end{abstract}

Keywords Total pancreatectomy $\cdot$ Robotic total pancreatectomy $\cdot$ Robotic pancreatectomy $\cdot$ Robotic pancreatoduodenectomy $\cdot$ Surgical complications $\cdot$ Pancreatic cancer

\section{Introduction}

Total pancreatectomy was initially introduced to avoid the consequences of post-operative pancreatic fistula [1] and to improve surgical radicality [2]. The procedure became very popular in the late ' 70 s and in the ' 80 s, when over $40 \%$ of pancreatic resections were total pancreatectomies [3]. Enthusiasm, however, was soon mitigated by the evidence that total pancreatectomy neither reduced post-operative

Ugo Boggi

u.boggi@med.unipi.it

1 Division of General and Transplant Surgery, University of Pisa, Pisa, Italy

2 Division of Anesthesia and Intensive Care, Azienda Ospedaliera Universitaria Pisana, Pisa, Italy mortality [4] nor improved long-term survival [5]. Additionally, total pancreatectomy decreases quality of life, by creating full exocrine and endocrine insufficiency [6]. Currently, total pancreatectomy is performed selectively, in approximately $6 \%$ of the patients who receive a pancreatic resection [7]. In the majority of these patients, total pancreatectomy is required due to widespread involvement of the gland [8] or in case of locally advanced tumors requiring arterial resection and reconstruction [9]. These indications may not apply well to a minimally invasive approach. However, total pancreatectomy may also be required in patients with positive frozen section histology of pancreatic neck margin during pancreaticoduodenectomy [10], multifocal endocrine tumors [11, 12], metastatic tumors [13], main duct intraductal papillary mucinous tumors [12, 14], premalignant lesions in patients with history of familial pancreatic 
cancer [8], extremely soft pancreatic remnants and small ducts in patients with right-sided tumors [15], and chronic pancreatitis with refractory pain [16]. In these patients, a minimally invasive approach may be an appealing alternative to open surgery. However, laparoscopic total pancreatectomy continues to be performed rarely. Barriers to wider adoption of laparoscopy for total pancreatectomy are likely to include the need for extensive retroperitoneal dissection while handling a rather bulky specimen in a deep space, the need to construct two digestive anastomoses, and the necessity to introduce several adaptations in respect to wellestablished open surgical techniques. At least in theory, the use of robotic assistance could facilitate the performance of all these tasks and could result in faster and safer implementation of minimally invasive total pancreatectomy.

In 2015, we reported on 11 cases of robotic-assisted total pancreatectomy (RATP) in the context of a matched analysis with open total pancreatectomy (OTP). In this study, we showed that RATP was feasible, despite longer operating times, and was associated with reduced blood loss, earlier achievement of independent mobility, earlier recovery of bowel functions, and improved pain scores with proportionally reduced need for post-operative analgesic therapy [17].

We herein present on 25 RATPs and provide a further comparison with contemporary cohort of OTPs matched by propensity scores.

\section{Methods}

This study was designed and reported according to the STROBE guidelines [18], and was approved by the Institutional Review Board of our hospital. Data were extracted from a prospectively maintained database and were analyzed retrospectively.

This study includes patients operated between October 2008 and December 2019 at the Division of General and Transplant Surgery of the Azienda Ospedaliera Universitaria Pisana, serving as the main referral center for surgical treatment of pancreatic diseases for approximately 1.2 million people, and receiving also patient referrals from all over Italy. At our Institution, the first da Vinci Surgical System (Intuitive Surgical ${ }^{\circledR}$, Sunnyvale, California, US) was installed in the year 2000 .

Selection criteria for RATP were: general suitability for laparoscopic surgery, absence of history of previous major upper abdominal surgery (e.g., partial or total gastrectomy, or major hepatectomy), body mass index $\leq 35 \mathrm{~kg}$ / $\mathrm{m}^{2}$, a preoperative diagnosis requiring total pancreatectomy while excluding locally advanced malignancy, and timely availability of the robot. Vein involvement without severe stenosis or obstruction was not considered an absolute contraindication.
To confirm that RATP is feasible and to further investigate its possible advantages, a control group was selected from a contemporary cohort of patients undergoing total pancreatectomy by an open approach.

To minimize bias from nonrandomized treatment assignment, RATP cases were matched with a 2:1 ratio with OTP controls using a conservative caliper width of 0.2 . The following parameters, known to predict post-operative outcomes in total pancreatectomy, were used: age $[19,20]$, gender [19, 20], body mass index [21], history of cardiac disease [22], American Society of Anesthesiologists (ASA) score [23, 24], history of weight loss [25], presence of jaundice [26], preoperative biliary drainage [27, 28], and involvement of the superior mesenteric/portal vein [23, 28].

The technique for RATP was previously described in detailed [17], and is shown in the attached video (supplementary material 1), but some important tips and tricks deserve a specific comment. First, in case of concurrent splenectomy, the left gastric vein should be preserved to avoid gastric congestion [29]. Second, when the spleen can be spared, preservation of the splenic vessels (alike in a Kimura procedure) is preferable [30] to avoid sinistral portal hypertension, but the lymph nodes located along the splenic vessels should be removed to ensure adequate staging [31]. Third, the first duodenal portion (or gastric antrum) should not be divided until the distal pancreas are fully mobilized to prevent retraction of the stomach in the left upper abdominal quadrant [17]. Fourth, during retroperitoneal dissection, large lymphatics should be sealed by ligatures or clips [32] to reduce incidence and severity of prolonged lymphatic drainage, including chyle leak [33].

In patients requiring vein resection and reconstruction, the vascular procedure was classified according to the International Study Group of Pancreatic Surgery [34].

\section{Definition of study outcomes}

Post-operative complications were graded using the Clavien-Dindo classification [35], and were considered severe when $\geq 3$. The comprehensive complication index (CCI) was also calculated [36]. Delayed gastric emptying (DGE) [37] and postpancreatectomy hemorrhage (PPH) [38] were defined according to the International Study Group on Pancreatic Surgery. Post-operative death, was defined as any death occurring during the initial hospital stay or the first 90 days after surgery.

Overall survival (OS), disease-free survival (DFS), and cancer-specific survival (CCS) were defined according to DATECAN (Definition for Assessment of Time-to-event End-points in CANcer trials) [39]. 


\section{Primary and secondary study endpoints}

The primary endpoint of this study was the rate of severe post-operative complications.

Secondary endpoints were: operating time, length of hospital stay, proportion of patients with grade 1-2 postoperative complications, CCI score, proportion of patients receiving blood transfusions, incidence and severity of $\mathrm{PPH}$, incidence and severity of DGE, need for repeat surgery at 90 days, number of examined lymph nodes, proportion of patients receiving adjuvant chemotherapy, proportion of patients completing adjuvant chemotherapy, OS, DFS, and CSS.

\section{Follow-up}

After hospital discharge patients were seen in our outpatient clinic at least once a month during the first 3 months and every 3 months thereafter. A computed tomography scan was obtained every 6 months for the first 5 years, and yearly thereafter.

\section{Statistical analysis}

The study was designed to demonstrate non-inferiority of RATP to OPT in terms of occurrence severe post-operative complications based on an intention-to-treat analysis that keeps in the minimally invasive group the patients who required conversion to open surgery. An overall rate of $22.5 \%$ [22] was assumed for both groups, and the noninferiority margin was set at $15 \%$. In addition, the $\alpha$ was set at 0.05 and $\beta$ at 0.20 , yielding a power of $80 \%$. Therefore, to demonstrate non-inferiority of experimental (i.e., RATP) and standard (i.e., OTP) a total of 50 patients would be required to be $80 \%$ certain that the upper limit of a onesided $97.5 \% \mathrm{CI}$-or equivalently a two-sided $95 \% \mathrm{CI}$ - would exclude a difference in favor of OPT exceeding $15 \%$.

Quantitative variables are presented as mean $\pm \mathrm{SD}$ if normally distributed, or as median and interquartile range (IQR) if not. Categorical variables are expressed as frequencies, percentages, and rates. Kolmogorov-Smirnov test was used to assess normality distribution. Chi-square test was used to evaluate the presence of an association between surgical technique (OPD and RPD) and outcome.

All statistical analyses were carried out with JMP ${ }^{\circledR}$ 15.2.0 software package for Mac, Copyright $\odot$ SAS Institute Inc., SAS campus Drive, Cary, NC, USA and R Package, R Core Team (2014): A language and Environment for Statistical Computing, R Foundation for Statistical Computing, Vienna AT using Matching, MatchIt and TrialSize as packages.
209

Total Pancreatectomies

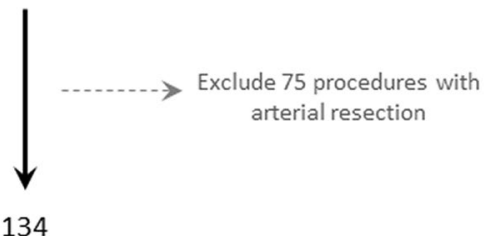

134

Total Pancreatectomies

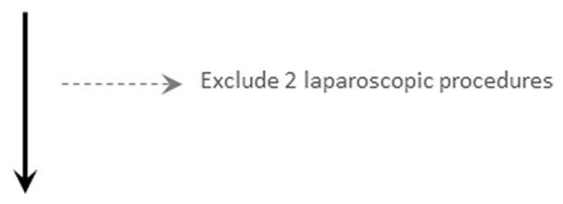

132

Total Pancreatectomies

(107 OTP - 25 RATP)

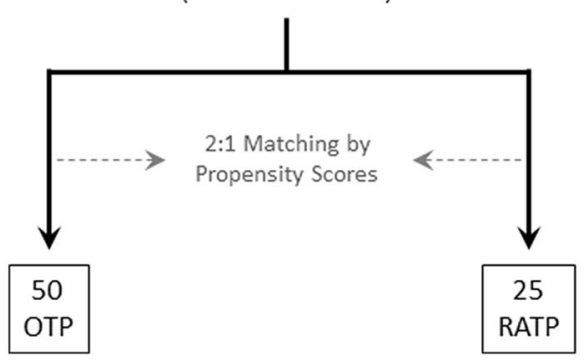

Fig. 1 Study flowchart

\section{Results}

During the study period, a total of 209 patients underwent total pancreatectomy. After exclusion of 75 patients with concurrent arterial resection and 2 patients operated laparoscopically, there were 132 patients who received either an OTP $(n=107)$ or a RATP $(n=25)$. After matching, there were 50 OTP and 25 RATP (Fig. 1).

Before matching, the two groups differed in prevalence of cardiac disease $(1 ; 4.0 \%$ versus $26 ; 24.3 \%)(p=0.03)$, presence of jaundice $(3 ; 12.0 \%$ versus $49 ; 45.8 \%)(p=0.002)$, need for a biliary drainage ( 0 versus $25 ; 23.4 \%)(p=0.004)$, history of weight loss $(2 ; 8.0 \%$ versus $30 ; 28.0 \%)(p=0.04)$, and vein involvement $(7 ; 28.0 \%$ versus $59 ; 55.1 \%)(p=0.03)$.

The matching process identified 75 patients, including 50 OTPs and 25 RATPs. As shown in Table 1, the two groups were fully matched for all baseline characteristics.

Fifteen RATPs (60\%) were two-stage procedures (i.e., resection was extended to achieve a radical resection following positive frozen section histology at the neck margin). The proportion of two-stage procedures was similar in the two groups ( $60 \%$ vs $48.6 \%$; $p=0.30$ ).

Conversion to open surgery was required in two RATPs $(8.0 \%)$. In both patients, conversion occurred under elective conditions because of unanticipated need for multivisceral 
Table 1 Baseline characteristics before and after 2:1 matching by propensity scores

\begin{tabular}{|c|c|c|c|c|c|c|c|c|}
\hline & \multicolumn{4}{|c|}{ Before matching } & \multicolumn{4}{|c|}{ After matching } \\
\hline & All & RATP & OTP & $p$ & All & RATP & OTP & $p$ \\
\hline Number of patients & $132(100 \%)$ & $25(18.9 \%)$ & $107(81.1 \%)$ & NA & $75(100 \%)$ & $25(33 \%)$ & $50(66.7 \%)$ & NA \\
\hline Age; years; mean $\pm S D$ & $67.2 \pm 10$ & $66.7 \pm 8.9$ & $67.1 \pm 1$ & 0.79 & $67.5 \pm 9.5$ & $67.7 \pm 8.9$ & $67.4 \pm 9.9$ & 0.9 \\
\hline Female gender; number $(\%)$ & $52(39.4 \%)$ & $12(48 \%)$ & $40(37.4 \%)$ & 0.33 & $33(44 \%)$ & $12(48 \%)$ & $21(42 \%)$ & 0.62 \\
\hline $\mathrm{BMI} ; \mathrm{kg} / \mathrm{m}^{2} ;$ mean $\pm \mathrm{SD}$ & $24.6 \pm 3.3$ & $23.7 \pm 2.2$ & $24.8 \pm 0.3$ & 0.17 & $23.8 \pm 2.5$ & $23.7 \pm 2.2$ & $23.8 \pm 2.6$ & 0.85 \\
\hline ASA score; median (IQR) & $3(2-3)$ & $3(2-3)$ & $3(3-3)$ & 0.15 & $3(2-3)$ & $3(2-3)$ & $3(2-3)$ & 0.71 \\
\hline Cardiac disease; number (\%) & $27(20.5 \%)$ & $1(4 \%)$ & $26(24.3 \%)$ & 0.03 & $6(8 \%)$ & $1(4 \%)$ & $5(10 \%)$ & 0.66 \\
\hline COPD; number (\%) & $15(11.4 \%)$ & $3(12 \%)$ & $12(11.2 \%)$ & 1 & $7(9.3 \%)$ & $3(12 \%)$ & $4(8 \%)$ & 0.68 \\
\hline Hypertension; number (\%) & $65(49.2 \%)$ & $14(56 \%)$ & $51(47.7 \%)$ & 0.45 & $35(46.7 \%)$ & $14(56 \%)$ & $21(42 \%)$ & 0.25 \\
\hline Diabetes mellitus; number (\%) & $49(37.1 \%)$ & $10(40 \%)$ & $39(36.5 \%)$ & 0.74 & $26(34.7 \%)$ & $10(40 \%)$ & $16(32 \%)$ & 0.49 \\
\hline Jaundice; number (\%) & $52(39.4 \%)$ & $3(12 \%)$ & $49(45.8 \%)$ & 0.002 & $12(16 \%)$ & $3(12 \%)$ & $9(18 \%)$ & 0.74 \\
\hline Abdominal pain; number (\%) & $66(50 \%)$ & $12(48 \%)$ & $54(50.5 \%)$ & 0.82 & $35(46.7 \%)$ & $12(48 \%)$ & $23(46 \%)$ & 0.87 \\
\hline Duodenal obstruction; number (\%) & $9(6.8 \%)$ & $2(8 \%)$ & $7(6.5 \%)$ & 0.68 & $5(6.7 \%)$ & $2(8 \%)$ & $3(6 \%)$ & 1 \\
\hline Weight loss; number (\%) & $32(24.2 \%)$ & $2(8 \%)$ & $30(28 \%)$ & 0.04 & $100(13.3 \%)$ & $2(8 \%)$ & $8(16 \%)$ & 0.48 \\
\hline Vein involvement; number (\%) & $66(50 \%)$ & $7(28 \%)$ & $59(55.1 \%)$ & $\mathbf{0 . 0 3}$ & $31(41.3 \%)$ & $7(28 \%)$ & $24(48 \%)$ & 0.10 \\
\hline Biliary drainage, number $(\%)$ & $25(18.9 \%)$ & $0(0 \%)$ & $25(23.4 \%)$ & 0.004 & $0(0 \%)$ & $0(0 \%)$ & $0(0 \%)$ & 0 \\
\hline Previous abdominal surgery; number $(\%)$ & $79(59.8 \%)$ & $15(60 \%)$ & $64(59.8 \%)$ & 0.99 & $46(61.3 \%)$ & $15(60 \%)$ & $31(62 \%)$ & 1 \\
\hline Preoperative chemotherapy; number (\%) & $9(6.8 \%)$ & $0(0 \%)$ & $9(8.4 \%)$ & 0.21 & $3(4 \%)$ & $0(0 \%)$ & $3(6 \%)$ & 0.55 \\
\hline
\end{tabular}

Statistically significant $p$ values are highlighted in bold

$B M I$ body mass index, ASA American Society of Anesthesiologists, $C O P D$ chronic obstructive pulmonary disease

resection and chronic inflammation of peripancreatic tissues precluding safe dissection, respectively.

As shown in Table 2, RATPs was associated with longer operating time, higher rates of pylorus preservation, and lower rates of type 3 vein reconstruction in both unmatched and matched cohorts. Before matching differences were also noted regarding the need for vein resection. Looking specifically at operative parameters in matched cohorts, it is worth to note that the main difference between the two groups was longer median operating time in RATPs (585; $525-637.5 \mathrm{~min}$ versus $475 ; 408.8-582.5 \mathrm{~min})(p=0.0003)$. Differences in rates of pylorus preservation $(23 ; 92.0 \%$ versus $35 ; 70.0 \%)(p=0.04)$, and rate of type 3 venous reconstruction $(3 ; 12.0 \%$ versus $18 ; 36.0 \%)(p=0.03)$ were also noted.

Regarding the main endpoint of this study, as shown in Table 3, severe post-operative complications developed in 6 patients $(24.0 \%)$ after RATP and in 13 patients (26.0\%) after OTP $(p=0.85)$. Overall, there were 9 post-operative deaths $(6.8 \%)$ in unmatched cohorts, and $5(6.7 \%)$ in matched cohorts with 1 death after RATP $(4.0 \%)$ and 4 deaths after OTP $(8.0 \%)(p=0.66)$.

Regarding the secondary endpoints of this study, differences in operating times were already presented. Concerning the remaining parameters, results achieved in the two study groups were equivalent with respect to length of hospital stay, proportion of patients with grade 1-2 post-operative complications, CCI score, proportion of patients receiving blood transfusions, incidence and severity of PPH, incidence and severity of DGE, need for repeat surgery at 90 days, number of examined lymph nodes, proportion of patients receiving adjuvant chemotherapy, proportion of patients completing adjuvant chemotherapy, and DFS (Tables 3, 4, and 5). RATPs was instead associated with longer overall OS and CSS (Fig. 2).

Details on histology of resected specimens are reported and oncologic follow-up are reported in in Tables 4 and 5, respectively.

\section{Discussion}

Total pancreatectomy is certainly a major procedure that, even when successful, imposes major consequences on patients resulting in impaired quality of life [6, 19]. Therefore, patients requiring a total pancreatectomy could not be considered good candidates for a minimally invasive procedure, which is typically performed to enhance patients' rehabilitation [40, 41], improve quality of life [42, 43], and minimize the impact of surgery on body image [44, 45]. On the other hand, in properly selected patients, total pancreatectomy could be conveniently performed through a minimally invasive approach, because it does not require a pancreatic anastomosis and therefore avoids post-operative 
Table 2 Operative time and procedures

\begin{tabular}{|c|c|c|c|c|c|c|c|c|}
\hline & \multicolumn{4}{|l|}{ Before matching } & \multicolumn{4}{|l|}{ After matching } \\
\hline & All & RATP & OTP & $p$ & All & RATP & OTP & $p$ \\
\hline Number of patients & $132(100 \%)$ & $25(18.9 \%)$ & $107(81.1 \%)$ & NA & $75(100 \%)$ & $25(33 . \%)$ & $50(66.7 \%)$ & NA \\
\hline $\begin{array}{l}\text { Operative time; } \\
\text { minutes; median } \\
\text { (IQR) }\end{array}$ & $520(445-610)$ & $585(525-637.5)$ & $500(430-600)$ & 0.002 & $520(445-605)$ & $585(525-637.5)$ & $475(408.8-582.5)$ & 0.0003 \\
\hline $\begin{array}{l}\text { En-bloc splenectomy } \\
(\%)\end{array}$ & $107(81.1 \%)$ & $18(72 \%)$ & $89(83.2 \%)$ & 0.20 & $60(80 \%)$ & $18(72 \%)$ & $42(84 \%)$ & 0.22 \\
\hline $\begin{array}{l}\text { Preservation of } \\
\text { spleen and splenic } \\
\text { vessels; number } \\
(\%)\end{array}$ & $25(18.9 \%)$ & $7(28 \%)$ & $18(16.8 \%)$ & 0.20 & $15(20 \%)$ & $7(28 \%)$ & $8(16 \%)$ & 0.22 \\
\hline $\begin{array}{l}\text { Pylorus preservation; } \\
\text { number }(\%)\end{array}$ & $91(68.9 \%)$ & $23(92 \%)$ & $68(63.6 \%)$ & 0.007 & $58(77.3 \%)$ & $23(92 \%)$ & $35(70 \%)$ & 0.04 \\
\hline $\begin{array}{l}\text { Total gastrectomy; } \\
\text { number }(\%)\end{array}$ & $6(4.5 \%)$ & $0(0 \%)$ & $6(5.6 \%)$ & 0.59 & $2(2.7 \%)$ & $0(0 \%)$ & $2(4 \%)$ & 0.55 \\
\hline $\begin{array}{l}\text { Multivisceral resec- } \\
\text { tion; number (\%) }\end{array}$ & $27(20.5 \%)$ & $2(8 \%)$ & $25(23.4 \%)$ & 0.1 & $16(21.3 \%)$ & $2(8 \%)$ & $14(28 \%)$ & 0.07 \\
\hline $\begin{array}{l}\text { Vein resection; num- } \\
\text { ber }(\%)\end{array}$ & $66(50 \%)$ & $7(28 \%)$ & $59(55.1 \%)$ & 0.03 & $31(41.3 \%)$ & $7(28 \%)$ & $24(48 \%)$ & 0.10 \\
\hline $\begin{array}{l}\text { Superior mesenteric } \\
\text { vein resection; } \\
\text { number }(\%)\end{array}$ & $11(8.3 \%)$ & $0(0 \%)$ & $11(10.3 \%)$ & 0.12 & $5(6.7 \%)$ & $0(0 \%)$ & $5(10 \%)$ & 0.16 \\
\hline $\begin{array}{l}\text { Portal vein resection; } \\
\text { number }(\%)\end{array}$ & $3(2.3 \%)$ & $2(8 \%)$ & $1(0.9 \%)$ & 0.09 & $2(2.7 \%)$ & $2(8 \%)$ & $0(0 \%)$ & 0.11 \\
\hline $\begin{array}{l}\text { Mesenteric-portal } \\
\text { confluence resec- } \\
\text { tion; number }(\%)\end{array}$ & $52(39.4 \%)$ & $5(20 \%)$ & $47(43.9 \%)$ & 0.03 & $24(32 \%)$ & $5(20 \%)$ & $19(38 \%)$ & 0.12 \\
\hline $\begin{array}{l}\text { Type } 3 \text { vein recon- } \\
\text { struction; number } \\
(\%)\end{array}$ & $48(36.4 \%)$ & $3(12 \%)$ & $45(42.1 \%)$ & 0.005 & $21(28 \%)$ & $3(12 \%)$ & $18(36 \%)$ & 0.03 \\
\hline $\begin{array}{l}\text { Type } 4 \text { vein recon- } \\
\text { struction; number } \\
(\%)\end{array}$ & $18(13.6 \%)$ & $4(16 \%)$ & $14(13.1 \%)$ & 0.74 & $10(13.3 \%)$ & $4(16 \%)$ & $6(12 \%)$ & 0.72 \\
\hline
\end{tabular}

Statistically significant $p$ values are highlighted in bold

pancreatic fistula by definition. Additionally, a minimally invasive approach has the potential to reduce some complications that occur frequently after total pancreatectomy such as DGE [19], pulmonary complications [19], abdominal infections [46], and surgical site infections [23].

RATP is a surgical innovation, since it is a "modified surgical procedure that differs from currently accepted local practice, the outcomes of which have not been described, and which may entail risk to the patient" [47]. When classified according to the Idea, Development, Exploration, Assessment, Long Term Study (IDEAL) recommendations [48], RATP has nearly completed stage 2 a (development) and is moving forward in stage $2 \mathrm{~b}$ (exploration). Stage $2 \mathrm{a}$ refers to a procedure that may still require technical refinements and that has been performed only in small groups of patients. Stage $2 b$ begins when the main technical aspects of the procedure have been fixed, but experience is still limited.
In both stages, outcomes should be recorded prospectively to ensure that all adverse events are captured. Reporting in stage $2 \mathrm{a}$ includes selection criteria, proportion of eligible patients, technical modifications, clinical outcomes, and specific complications. Reporting in stage $2 \mathrm{~b}$ should mostly consist of clinical studies providing preparatory information for subsequent major randomized clinical studies [48].

According to this background, this study provides the highest possible level of evidence for a procedure in stage $2 a-2 b$ in the IDEAL framework (i.e., RATP), by assessing safety (i.e., incidence of severe post-operative complications) in the context of a propensity score matched comparison with the current treatment standard (i.e., OTP). Our data show that RATP is non-inferior to OTP with respect to occurrence of SPC. The relevance of this piece of information is enhanced by the fact that our results were achieved in the first 25 RATPs. Despite the learning curve 
Table 3 Post-operative results

\begin{tabular}{|c|c|c|c|c|c|c|c|c|}
\hline & \multicolumn{4}{|c|}{ Before matching } & \multicolumn{4}{|l|}{ After matching } \\
\hline & All & RATP & OTP & $p$ & All & RATP & OTP & $p$ \\
\hline Number of patients & $132(100 \%)$ & $25(18.9 \%)$ & $107(81.1 \%)$ & NA & $75(100 \%)$ & $25(33 \%)$ & $50(66.7 \%)$ & NA \\
\hline Length of stay; median (IQR); days & $20(15-30)$ & $22(14.5-30.5)$ & $19(15-30)$ & 0.54 & $20(14-28)$ & $22(14.5-30.5)$ & $18(14-28)$ & 0.19 \\
\hline $\begin{array}{l}\text { Patients receiving blood transfusions; } \\
\text { number }(\%)\end{array}$ & $40(30.3 \%)$ & $5(20 \%)$ & $35(32.7 \%)$ & 0.21 & $24(32 \%)$ & $5(20 \%)$ & $19(38 \%)$ & 0.12 \\
\hline $\begin{array}{l}\text { Patients without complications; } \\
\text { number }(\%)\end{array}$ & $42(31.8 \%)$ & $7(28 \%)$ & $35(32.7 \%)$ & 0.65 & $27(36 \%)$ & $7(28 \%)$ & $20(40 \%)$ & 0.31 \\
\hline $\begin{array}{l}\text { Patients with grade I complications; } \\
\text { number }(\%)\end{array}$ & $3(2.3 \%)$ & $0(0 \%)$ & $3(2.8 \%)$ & 1 & $1(1.3 \%)$ & $0(0 \%)$ & $1(2 \%)$ & 1 \\
\hline $\begin{array}{l}\text { Patients with grade II complications; } \\
\text { number }(\%)\end{array}$ & $50(37.9 \%)$ & $12(48 \%)$ & $38(35.5 \%)$ & 0.25 & $28(37.3 \%)$ & $12(48 \%)$ & $16(32 \%)$ & 0.18 \\
\hline $\begin{array}{l}\text { Patients with grade IIIa complica- } \\
\text { tions; number }(\%)\end{array}$ & $13(9.8 \%)$ & $4(16 \%)$ & $9(8.4 \%)$ & 0.27 & $7(9.3 \%)$ & $4(16 \%)$ & $3(6 \%)$ & 0.21 \\
\hline $\begin{array}{l}\text { Patients with grade IIIb complica- } \\
\text { tions; number }(\%)\end{array}$ & $6(4.5 \%)$ & $0(0 \%)$ & $6(5.6 \%)$ & 0.59 & $4(5.3 \%)$ & $0(0 \%)$ & $4(8 \%)$ & 0.29 \\
\hline $\begin{array}{l}\text { Patients with grade IVa complica- } \\
\text { tions; number }(\%)\end{array}$ & $8(6.1 \%)$ & $1(4 \%)$ & $7(6.5 \%)$ & 1 & $3(4 \%)$ & $1(4 \%)$ & $2(4 \%)$ & 1 \\
\hline $\begin{array}{l}\text { Patients with grade IVb complica- } \\
\text { tions; number }(\%)\end{array}$ & $1(0.8 \%)$ & $0(0 \%)$ & $1(0.9 \%)$ & 1 & $0(0.0 \%)$ & $0(0 \%)$ & $0(0 \%)$ & NA \\
\hline $\begin{array}{l}\text { Patients with grade } \mathrm{V} \text { complications; } \\
\text { number }(\%)\end{array}$ & $9(6.8 \%)$ & $1(4 \%)$ & $8(7.5 \%)$ & 1 & $5(6.7 \%)$ & $1(4 \%)$ & $4(8 \%)$ & 0.66 \\
\hline $\begin{array}{l}\text { Patients with severe complications } \\
(\geq 3 \mathrm{a}) ; \text { number }(\%)\end{array}$ & $37(28 \%)$ & $6(24 \%)$ & $31(29 \%)$ & 0.62 & $19(25.3 \%)$ & $6(24 \%)$ & $13(26 \%)$ & 0.85 \\
\hline $\begin{array}{l}\text { Comprehensive Complication Index; } \\
\text { median (IQR) }\end{array}$ & $22.6(0-33.7)$ & $20.9(0-32.5)$ & $22.6(0-36.2)$ & 0.76 & $20.9(0-29.6)$ & $20.9(0-32.5)$ & $20.9(0-39.6)$ & 0.72 \\
\hline $\begin{array}{l}\text { Post-pancreatectomy hemorrhage; } \\
\text { number }(\%)\end{array}$ & $10(7.6 \%)$ & $2(8 \%)$ & $8(7.5 \%)$ & 1 & $7(9.3 \%)$ & $2(8 \%)$ & $5(10 \%)$ & 1 \\
\hline Grade A; number (\%) & $1(0.8 \%)$ & $0(0 \%)$ & $1(0.9 \%)$ & 1 & $0(0.0 \%)$ & $0(0 \%)$ & $0(0 \%)$ & NA \\
\hline Grade B; number (\%) & $4(3 \%)$ & $1(4 \%)$ & $3(2.8 \%)$ & 0.57 & $3(4 \%)$ & $1(4 \%)$ & $2(4 \%)$ & 1 \\
\hline Grade C; number (\%) & $5(3.8 \%)$ & $1(4 \%)$ & $4(3.7 \%)$ & 1 & $4(5.3 \%)$ & $1(4 \%)$ & $3(6 \%)$ & 1 \\
\hline $\begin{array}{l}\text { Delayed gastric emptying; number } \\
(\%)\end{array}$ & $14(10.6 \%)$ & $6(24 \%)$ & $8(7.5 \%)$ & 0.02 & $11(14.7 \%)$ & $6(24 \%)$ & $5(10 \%)$ & 0.11 \\
\hline Grade A; number (\%) & $0(0 \%)$ & $0(0 \%)$ & $0(0 \%)$ & NA & $0(0 \%)$ & $0(0 \%)$ & $0(0 \%)$ & NA \\
\hline Grade B; number (\%) & $11(8.3 \%)$ & $4(16 \%)$ & $7(6.5 \%)$ & 0.22 & $8(10.7 \%)$ & $4(16 \%)$ & $4(8 \%)$ & 0.43 \\
\hline Grade C; number (\%) & $3(2.3 \%)$ & $2(8 \%)$ & $1(0.9 \%)$ & 0.09 & $3(4 \%)$ & $2(8 \%)$ & $1(2 \%)$ & 0.26 \\
\hline Biliary leak; number (\%) & $3(2.3 \%)$ & $0(0 \%)$ & $3(2.8 \%)$ & 1 & $1(1.3 \%)$ & $0(0 \%)$ & $1(2 \%)$ & 1 \\
\hline Enteric fistula; number (\%) & $5(3.8 \%)$ & $0(0 \%)$ & $5(4.5 \%)$ & 0.58 & $3(4 \%)$ & $0(0 \%)$ & $3(6 \%)$ & 0.55 \\
\hline Medical complications; number (\%) & $71(53.8 \%)$ & $11(44 \%)$ & $60(56.1 \%)$ & 0.28 & $35(46.7 \%)$ & $11(44 \%)$ & $24(48 \%)$ & 0.74 \\
\hline $\begin{array}{l}\text { Repeat surgery at } 90 \text { days; number } \\
(\%)\end{array}$ & $17(12.9 \%)$ & $2(8 \%)$ & $15(14 \%)$ & 0.53 & $9(12 \%)$ & $2(8 \%)$ & $7(14 \%)$ & 0.71 \\
\hline
\end{tabular}

Statistically significant $p$ value is highlighted in bold

for robotic total pancreatectomy has not been defined yet, and could be influenced by contemporary volume of other types of pancreatic resections, it is reasonable to accept that with further experience, we should be able to reduce our operating times. As longer operating times were one of the main difference between RATP and OTP, and duration of surgery exceeding $420 \mathrm{~min}$ is a strong prognostic factor for the development of post-operative complications [19], future results could be more favorable.

\section{Technical considerations}

Despite total pancreatectomy is almost automatically associated with the concept of splenectomy, we could preserve the spleen along with the splenic vessels in 18 of 107 OTPs (16.8\%) and in 7 of 25 (28.0\%) RATPs. Other series have shown rates of spleen preservation ranging from 6.4 to $34 \%$ $[19,20]$.

In general, spleen preservation is considered to be important to reduce intraoperative bleeding [49], to 
Table 4 Pathology of resected specimens

\begin{tabular}{|c|c|c|c|c|c|c|c|c|}
\hline & \multicolumn{4}{|c|}{ Before matching } & \multicolumn{4}{|c|}{ After matching } \\
\hline & All & RATP & OTP & $p$ & All & RATP & OTP & $p$ \\
\hline Number of patients & $132(100 \%)$ & $25(18.9 \%)$ & $107(81.1 \%)$ & NA & $75(100 \%)$ & $25(33 \%)$ & $50(66.7 \%)$ & NA \\
\hline \multicolumn{9}{|l|}{ Tumor types } \\
\hline Pancreatic ductal adenocarcinoma; number (\%) & $45(34.1 \%)$ & $5(20 \%)$ & $40(37.4 \%)$ & 0.10 & $20(26.7 \%)$ & $5(20 \%)$ & $15(30 \%)$ & 0.42 \\
\hline Malignant IPMN; number (\%) & $47(35.6 \%)$ & $11(44 \%)$ & $36(33.6 \%)$ & 0.33 & $26(34.7 \%)$ & $11(44 \%)$ & $15(30 \%)$ & 0.23 \\
\hline IPMN; number (\%) & $19(14.4 \%)$ & $7(28 \%)$ & $12(11.2 \%)$ & 0.03 & $17(22.7 \%)$ & $7(28 \%)$ & $10(20 \%)$ & 0.44 \\
\hline Ampullary carcinoma; number $(\%)$ & $2(1.5 \%)$ & $0(0 \%)$ & $2(1.9 \%)$ & 1 & $0(0 \%)$ & $0(0 \%)$ & $0(0 \%)$ & NA \\
\hline Duodenal adenocarcinoma; number (\%) & $1(0.8 \%)$ & $0(0 \%)$ & $1(0.9 \%)$ & 1 & $1(1.3 \%)$ & $0(0 \%)$ & $1(2 \%)$ & 1 \\
\hline Acinar cell carcinoma; number $(\%)$ & $1(0.8 \%)$ & $0(0 \%)$ & $1(0.9 \%)$ & 1 & $0(0 \%)$ & $0(0 \%)$ & $0(0 \%)$ & NA \\
\hline Gastric cancer; number $(\%)$ & $1(0.8 \%)$ & $0(0 \%)$ & $1(0.9 \%)$ & 1 & $0(0 \%)$ & $0(0 \%)$ & $0(0 \%)$ & NA \\
\hline Metastasis from renal cell carcinoma; number (\%) & $6(4.5 \%)$ & $1(4 \%)$ & $5(4.7 \%)$ & 1 & $5(6.7 \%)$ & $1(4 \%)$ & $4(8 \%)$ & 0.66 \\
\hline Chronic pancreatitis; number (\%) & $6(4.5 \%)$ & $1(4 \%)$ & $5(4.7 \%)$ & 1 & $3(4 \%)$ & $1(4 \%)$ & $2(4 \%)$ & 1 \\
\hline Neuroendocrine tumor; number $(\%)$ & $3(2.3 \%)$ & $0(0 \%)$ & $3(2.8 \%)$ & 1 & $2(2.7 \%)$ & $0(0 \%)$ & $2(4 \%)$ & 1 \\
\hline Lymphoma; number (\%) & $1(0.8 \%)$ & $0(0 \%)$ & $1(0.9 \%)$ & 1 & $1(1.3 \%)$ & $0(0 \%)$ & $1(2 \%)$ & 1 \\
\hline Number of examined lymph nodes; mean \pm SD & $63.3 \pm 27.2$ & $66.1 \pm 5.5$ & $62.6 \pm 2.6$ & 0.57 & $61 \pm 25.8$ & $66.1 \pm 5.5$ & $58.4 \pm 24$ & 0.26 \\
\hline Number of positive lymph nodes; median (IQR) & $1(0-4)$ & $0(0-1)$ & $1(0-5)$ & 0.02 & $0(0-3)$ & $0(0-1)$ & $0(0-5.3)$ & 0.25 \\
\hline Patients with positive margins ${ }^{\mathrm{a}} ;$ number $(\%)$ & $30(30.9 \%)$ & $4(25 \%)$ & $26(32.1 \%)$ & 0.77 & $14(29.8 \%)$ & $4(25 \%)$ & $10(32.3 \%)$ & 0.74 \\
\hline $\begin{array}{l}\text { Patients with confirmed vascular invasion; number } \\
(\%)\end{array}$ & $42(63.6 \%)$ & $4(57.1 \%)$ & $38(64.4 \%)$ & 0.70 & $22(71 \%)$ & $4(57.1 \%)$ & $18(75 \%)$ & 0.38 \\
\hline Length of resected vein segment; $\mathrm{cm} ;$ mean $\pm \mathrm{SD}$ & $3.1 \pm 1.1$ & $2.1 \pm 0.5$ & $3.2 \pm 1.1$ & 0.009 & $2.8 \pm 1$ & $2.1 \pm 0.5$ & $2.9 \pm 1$ & 0.04 \\
\hline
\end{tabular}

Statistically significant $p$ values are highlighted in bold

$I P M N$ intraductal papillary mucinous neoplasm

${ }^{a}$ Margins are assessed circumferentially and at $1 \mathrm{~mm}$

Table 5 Oncologic follow-up in patients with pancreatic cancer and malignant IPMN (not including post-operative deaths)

\begin{tabular}{|c|c|c|c|c|c|c|c|c|}
\hline & \multicolumn{4}{|l|}{ Before matching } & \multicolumn{4}{|l|}{ After matching } \\
\hline & All & RATP & OTP & $p$ & All & RATP & OTP & $p$ \\
\hline Patients number (\%) & $83(62.9 \%)$ & $15(60 \%)$ & $68(63.6 \%)$ & 0.74 & $41(54.7 \%)$ & $15(60 \%)$ & $26(52 \%)$ & 0.51 \\
\hline $\begin{array}{l}\text { Patients receiving adju- } \\
\text { vant chemotherapy; } \\
\text { number }(\%)\end{array}$ & $57(60.6 \%)$ & $7(46.7 \%)$ & $50(63.3 \%)$ & 0.23 & $26(56.5 \%)$ & $7(46.7 \%)$ & $19(61 \%)$ & 0.35 \\
\hline $\begin{array}{l}\text { Patients completing } \\
\text { adjuvant chemother- } \\
\text { apy; number }(\%)\end{array}$ & $43(62.3 \%)$ & $9(75 \%)$ & $34(59.7 \%)$ & 0.32 & $22(66.7 \%)$ & $9(75 \%)$ & $13(61.9 \%)$ & 0.44 \\
\hline $\begin{array}{l}\text { Overall survival; } \\
\text { months; median (IQR) }\end{array}$ & $27.3(10.2-\mathrm{NA})$ & NA (27.3-NA) & $23.3(9.8-\mathrm{NA})$ & 0.004 & 43.5 (12.2-NA) & NA (27.3-NA) & $22.6(11.2-81.2)$ & 0.006 \\
\hline $\begin{array}{l}\text { Cancer specific sur- } \\
\text { vival; months; median } \\
\text { (IQR) }\end{array}$ & $27.3(10.2-\mathrm{NA})$ & NA (27.3-NA) & 23.3 (9.8-NA) & 0.006 & NA (12.2-NA) & NA (27.3-NA) & 22.6 (11.2-NA) & 0.02 \\
\hline $\begin{array}{l}\text { Disease-free survival; } \\
\text { months; median (IQR) }\end{array}$ & $9.1(4.5-15.5)$ & $7.6(7.6-7.6)$ & $10.1(4-16)$ & 0.63 & $10.5(5.5-19.07)$ & $7.6(7.6-7.6)$ & $11.2(5.5-19.7)$ & 0.58 \\
\hline
\end{tabular}

Statistically significant $p$ values are highlighted in bold

$R T P D$ robot-assisted total pancreatoduodenectomy, $O T P$ open total pancreaticoduodenectomy

decrease the risk of thromboembolic events [50], and to prevent overwhelming post splenectomy spesis [51]. In patients diagnosed with pancreatic tumors, splenectomy does not improve oncologic radicality, mostly due to the rare occurrence of lymph-node metastasis at the splenic hilum [52, 53], and was instead shown to reduce long-term 
Fig. 2 Kaplan-Meier curves for cancer-specific survival for matched patients undergoing either OPD (red line) or RATP (blue line) for pancreatic cancer or malignant IPMN

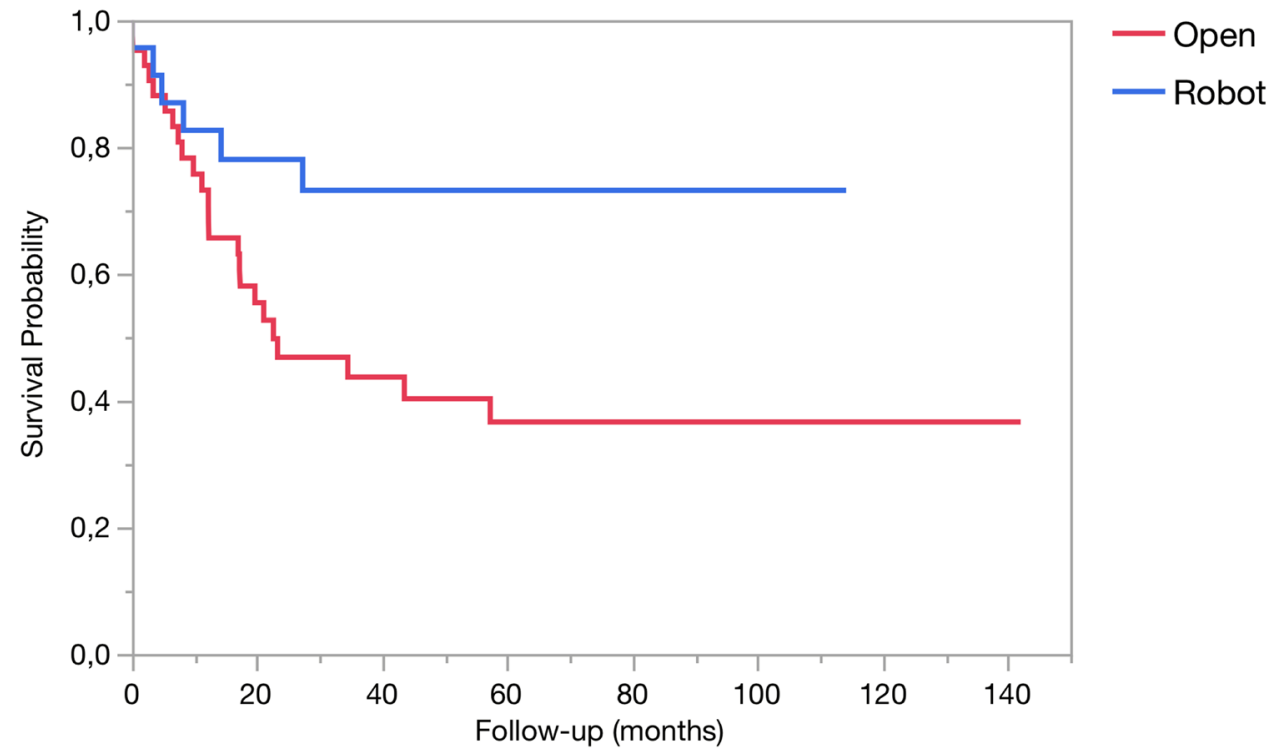

survival [54] as already shown for the stomach [55] and the colon [56]. Finally, several in-vitro studies have demonstrated that the spleen plays in antitumor immune response and that splenectomy could facilitate development of distant metastasis $[57,58]$. The robotic approach is known to facilitate spleen preservation during distal pancreatectomy, especially using the Kimura technique [59]. Although the spleen can be preserved also when sacrificing the splenic vessels, alike in a Warshaw procedure [60], we do not favor this approach in total pancreatectomy, since spleen supply would be left to a collateral circulation based on the left gastric vessels alone.

Considering that pylorus preservation is standard at our Institution [61], the higher ability to meet this goal with RATP $(92.0 \%$ versus $70.0 \%)$ might mean that the robotic assistance improves the ability to preserve blood supply to the entire stomach when extensive retroperitoneal dissection is required.

In general, in patients requiring a vein resection, we favor segmental over tangential vein resection [62, 63]. In our hands and in the open setting, most of these procedures are currently type 3 vein resections/reconstructions. In RATP, we noted fewer direct, end-to-end, vein reconstructions with a proportional increase in type 4 procedures. This can be readily explained by the need to place the patient in reverse Trendelenburg position [17] and the relative inability to perform a Cattell-Braasch maneuver [64]. Due to these challenges, other groups prefer to pursue type 1-2 vein resections/reconstructions during minimally invasive procedures [65-68]. While all technical solutions are acceptable, provided that the opportunity of achieving a radical resection is not missed and vein patency is maintained, we recommend that surgeons should have a clear strategy for vein resection and reconstruction before embarking upon these procedures.
These strategies might be different from those established in the open setting.

\section{Length of hospital stay as a surrogate marker of early recovery}

Most studies on minimally invasive procedures emphasize the importance of reduced length of hospital stay (versus open surgery). In some studies, especially from the United States, hospital stay may be very short, even in case of major procedures. In this study, we have not reported a short hospital stay after RATP. While achieving this goal is certainly important for stakeholders, it should be recognized that length of hospital stay may not be an objective parameter to evaluate the efficacy of surgical procedures, since it can be influenced by external factors, such as local and cultural attitudes [32]. Additionally, after total pancreatectomy, patients need to be trained to manage brittle diabetes before they can safely leave the hospital [69]. Finally, patients living far from hospital may feel unsecure if discharged too early, and may not accept this decision. We therefore suggest the use of more objective parameters, such as time to functional recovery [70], to show efficacy of post-operative recovery in surgical procedures.

\section{Other reports on RATP}

An analysis of current literature demonstrates only few case reports $[12,71,72]$ and small series $[12,14,17,46$, 73 ] reporting on either laparoscopic total pancreatectomy or RATP. Excluding our previous study [17], there is only one additional study comparing matched cohorts of RATP and OTP. In this study, Weng and co-workers report on 15 RATP and 78 OTP performed over a period of slightly more than 
4 years at a Chinese center performing an average over 1000 pancreatic resections per year [46]. In unmatched cohorts, the two groups differed in BMI (lower in RATP), incidence of vascular involvement (less frequent in RATP), presence of variations in arterial liver supply (less frequent in RATP), rate of spleen preservation (higher in RATP), median length of hospital stay (shorter in RATP), number of examined lymph nodes (lower in RATP), and operating time (shorter in RATP). After 1:1 matching by propensity scores all differences but shorter operating time in RATP disappeared. This study confirmed that RATP, in selected patients, is not associated with an increased risk of post-operative complications. Actually, these authors reported impressively low rates of SPC after either RATP $(6.7 \%)$ or OTP $(14.1 \%)$. These figures should be carefully interpreted as they refer to a follow-up of only 30 days and were achieved in the context of a patient population in which two-thirds of the patients were classified $\leq$ ASA 2. Additionally, it is not clear how this group could achieve shorter operating times in the robotic group, but their impressively high annual volumes of robotic pancreatic resections (approximately 300 procedures per year) reinforce the concept that with enough practice operating times can be significantly reduced. It is also worth to note that even if length of hospital stay was shorter in the robotic group (18 versus 20 days), these figures are similar to our results (22 versus 18 days). Also the rate of spleen preservation in the robotic group (26.7\%) is similar to the one recorded in our series $(28.0 \%)$, further reinforcing the concept that robotic assistance facilitates spleen preservation [46].

\section{Study limitations}

This study has several limitations. First, despite prospective collection of data, the retrospective analysis carries the inherent risk of hidden biases mostly related to patient selection. Second, despite reporting on one of the largest series of minimally invasive total pancreatectomies, the relatively small number of procedures may not be sufficient enough to depict the full spectrum and severity of complications occurring following RATPs. Third, this series of RATPs was performed at a single institution, thereby limiting the generalizability of the results.

\section{Conclusions}

In conclusion, despite the above-mentioned limitations, our data show that RATP in selected patients is non-inferior to OTP regarding occurrence of severe post-operative complications. Therefore, this study contributes to define the role of robotic assistance in very complex procedures, such as total pancreatectomy.
We wish to underscore that the 25 RATPs reported herein constitute approximately $6 \%$ of our experience with robotic pancreatic resections and $<2 \%$ of our overall volume of pancreatic resections during the study period. Reproducibility of our results in centers with lower volumes of activity remains to be established.

Supplementary Information The online version contains supplementary material available at https://doi.org/10.1007/s13304-021-01079-3.

Author contributions Substantial contributions were made to the conception or design of the work (UB), the acquisition, analysis (EFK, NN, VG, MG, CG, FV, and GA), interpretation of data for the work (EFK, $\mathrm{NN}$ and $\mathrm{UB}$ ), drafting of the work (GA, and UB) or revising it critically for important intellectual content (EFK, NN, VG, MG, CG, FV, GA, and UB), and final approved of the version to be published (EFK, NN, VG, MG, CG, FV, GA, and UB). Agreement to be accountable for all aspects of the work in ensuring that questions related to the accuracy or integrity of any part of the work are appropriately investigated and resolved (EFK, NN, VG, MG, CG, FV, GA, and UB).

Funding Open access funding provided by Università di Pisa within the CRUI-CARE Agreement. This research did not receive any specific grant from funding agencies in public, commercial, or non-profit sectors.

Availability of data and materials All materials are available upon request.

\section{Declarations}

Conflict of interest The authors declare they have no conflict of interest. No preregistration exists for the studies reported in this article.

Research involving human participants and/or animals Not applicable.

Informed consent and ethical approval The Institutional Review Board of the University of Pisa approved this study.

Open Access This article is licensed under a Creative Commons Attribution 4.0 International License, which permits use, sharing, adaptation, distribution and reproduction in any medium or format, as long as you give appropriate credit to the original author(s) and the source, provide a link to the Creative Commons licence, and indicate if changes were made. The images or other third party material in this article are included in the article's Creative Commons licence, unless indicated otherwise in a credit line to the material. If material is not included in the article's Creative Commons licence and your intended use is not permitted by statutory regulation or exceeds the permitted use, you will need to obtain permission directly from the copyright holder. To view a copy of this licence, visit http://creativecommons.org/licenses/by/4.0/.

\section{References}

1. Ross DE (1954) Cancer of the pancreas; a plea for total pancreatectomy. Am J Surg 87:20-33. https://doi.org/10.1016/00029610(54)90038-0

2. Porter MR (1958) Carcinoma of the pancreatico-duodenal area; operability and choice of procedure. Ann Surg 148:711-723. 
https://doi.org/10.1097/00000658-195810000-00017 (discussion 723-724)

3. Connolly MM, Dawson PJ, Michelassi F, Moossa AR, Lowenstein F (1987) Survival in 1001 patients with carcinoma of the pancreas. Ann Surg 206:366-373. https://doi.org/10.1097/00000 658-198709000-00015

4. Bhayani NH, Miller JL, Ortenzi G, Kaifi JT, Kimchi ET, Staveley-O'Carroll KF, Gusani NJ (2014) Perioperative outcomes of pancreaticoduodenectomy compared to total pancreatectomy for neoplasia. J Gastrointest Surg 18:549-554. https://doi.org/10. 1007/s11605-013-2393-0

5. Reddy S, Wolfgang CL, Cameron JL, Eckhauser F, Choti MA, Schulick RD, Edil BH, Pawlik TM (2009) Total pancreatectomy for pancreatic adenocarcinoma: evaluation of morbidity and longterm survival. Ann Surg 250:282-287. https://doi.org/10. 1097/SLA.0b013e3181ae9f93

6. Stoop TF, Ateeb Z, Ghorbani P, Scholten L, Arnelo U, Besselink MG, Del Chiaro M (2020) Impact of endocrine and exocrine insufficiency on quality of life after total pancreatectomy. Ann Surg Oncol 27:587-596. https://doi.org/10.1245/s10434-019-07853-3

7. Janot MS, Belyaev O, Kersting S, Chromik AM, Seelig MH, Sülberg D, Mittelkötter U, Uhl WH (2010) Indications and early outcomes for total pancreatectomy at a high-volume pancreas center. HPB Surg. https://doi.org/10.1155/2010/686702

8. Heidt DG, Burant C, Simeone DM (2007) Total pancreatectomy: indications, operative technique, and postoperative sequelae. J Gastrointest Surg 11:209-216. https://doi.org/10.1007/ s11605-006-0025-7

9. Napoli N, Kauffmann E, Cacace C, Menonna F, Caramella D, Cappelli C, Campani D, Cacciato Insilla A, Vasile E, Vivaldi C, Fornaro L, Amorese G, Vistoli F, Boggi U (2021) Factors predicting survival in patients with locally advanced pancreatic cancer undergoing pancreatectomy with arterial resection. Updates Surg 2021(73):233-249. https://doi.org/10.1007/s13304-020-00883-7

10. Crippa S, Tamburrino D, Partelli S, Salvia R, Germenia S, Bassi C, Pederzoli P, Falconi M (2011) Total pancreatectomy: indications, different timing, and perioperative and long-term outcomes. Surgery 149:79-86. https://doi.org/10.1016/j.surg.2010.04.007

11. Dallemagne B, de Oliveira AT, Lacerda CF, D'Agostino J, Mercoli H, Marescaux J (2013) Full laparoscopic total pancreatectomy with and without spleen and pylorus preservation: a feasibility report. J Hepatobiliary Pancreat Sci 20(6):647-653. https://doi.org/10.1007/s00534-013-0593-3

12. Casadei R, Marchegiani G, Laterza M, Ricci C, Marrano N, Margiotta A, Minni F (2009) Total pancreatectomy: doing it with a mini-invasive approach. JOP 10:328-331

13. Konstantinidis IT, Dursun A, Zheng H, Wargo JA, Thayer SP, Fernandez-del Castillo C, Warshaw AL, Ferrone CR (2010) Metastatic tumors in the pancreas in the modern era. J Am Coll Surg 211:749-753. https://doi.org/10.1016/j.jamcollsurg.2010. 08.017

14. Choi SH, Hwang HK, Kang CM, Yoon CI, Lee WJ (2012) Pylorus- and spleen-preserving total pancreatoduodenectomy with resection of both whole splenic vessels: feasibility and laparoscopic application to intraductal papillary mucin-producing tumors of the pancreas. Surg Endosc 26:2072-2077. https://doi. org/10.1007/s00464-011-2113-3

15. Balzano G, Maffi P, Nano R, Zerbi A, Venturini M, Melzi R, Mercalli A, Magistretti P, Scavini M, Castoldi R, Carvello M, Braga M, Del Maschio A, Secchi A, Staudacher C, Piemonti L (2013) Extending indications for islet autotransplantation in pancreatic surgery. Ann Surg 258:210-218. https://doi.org/10.1097/SLA. 0b013e31829c790d

16. Bramis K, Gordon-Weeks AN, Friend PJ, Bastin E, Burls A, Silva MA, Dennison AR (2012) Systematic review of total pancreatectomy and islet autotransplantation for chronic pancreatitis. Br J Surg 99:761-766. https://doi.org/10.1002/bjs.8713

17. Boggi U, Palladino S, Massimetti G, Vistoli F, Caniglia F, De Lio N, Perrone V, Barbarello L, Belluomini M, Signori S, Amorese G, Mosca F (2015) Laparoscopic robot-assisted versus open total pancreatectomy: a case-matched study. Surg Endosc 29:14251432. https://doi.org/10.1007/s00464-014-3819-9

18. Von Elm E, Altman DG, Egger M, Pocock SJ, Gøtzsche PC, Vandenbroucke JP, Initiative STROBE (2007) The Strengthening the reporting of observational studies in epidemiology (STROBE) statement: guidelines for reporting observational studies. Lancet 370(9596):1453-1457

19. Pulvirenti A, Pea A, Rezaee N, Gasparini C, Malleo G, Weiss MJ, Cameron JL, Wolfgang CL, He J, Salvia R (2019) Perioperative outcomes and long-term quality of life after total pancreatectomy. Br J Surg 106:1819-1828. https://doi.org/10.1002/bjs.11185

20. Müller MW, Friess H, Kleeff J, Dahmen R, Wagner M, Hinz U, Breisch-Girbig D, Ceyhan GO, Büchler MW (2007) Is there still a role for total pancreatectomy? Ann Surg. 246(6):966-974. https:// doi.org/10.1097/SLA.0b013e31815c2ca3 (discussion 974-5)

21. He S, Ding D, Wright MJ, Groshek L, Javed AA, Ka-Wan Chu K, Burkhart RA, Cameron JL, Weiss MJ, Wolfgang CL, He J (2020) The impact of high body mass index on patients undergoing robotic pancreatectomy: a propensity matched analysis. Surgery 167:556-559. https://doi.org/10.1016/j.surg.2019.11.002

22. Dovzhanskiy DI, Hackert T, Krumm J, Hinz U, Roggenbach J, Hofer S, Büchler MW, Werner J (2014) Clinical impact of perioperative myocardial infarction after pancreatic surgery. J Gastrointest Surg 18:929-934. https://doi.org/10.1007/s11605-014-2453-0

23. Hashimoto D, Mizuma M, Kumamaru H, Miyata H, Chikamoto A, Igarashi H, Itoi T, Egawa S, Kodama Y, Satoi S, Hamada S, Mizumoto K, Yamaue H, Yamamoto M, Kakeji Y, Seto Y, Baba H, Unno M, Shimosegawa T, Okazaki K (2020) Risk model for severe postoperative complications after total pancreatectomy based on a nationwide clinical database. Br J Surg 107:734-742. https://doi.org/10.1002/bjs.11437

24. Hartwig W, Gluth A, Hinz U, Bergmann F, Spronk PE, Hackert T, Werner J, Büchler MW (2015) Total pancreatectomy for primary pancreatic neoplasms: renaissance of an unpopular operation. Ann Surg 261(3):537-546. https://doi.org/10.1097/SLA.0000000000 000791

25. Perrone VG, Iacopi S, Amorese G, Boggi U (2020) Impact of nutritional status on outcome of pancreatic resections for pancreatic cancer and periampullary tumors. Hepatobiliary Surg Nutr 9:669-672. https://doi.org/10.21037/hbsn-20-498

26. Shen Z, Zhang J, Zhao S, Zhou Y, Wang W, Shen B (2020) Preoperative biliary drainage of severely obstructive jaundiced patients decreases overall postoperative complications after pancreaticoduodenectomy: a retrospective and propensity score-matched analysis. Pancreatology 20:529-536. https://doi.org/10.1016/j. pan.2020.02.002

27. Limongelli P, Pai M, Bansi D, Thiallinagram A, Tait P, Jackson J, Habib NA, Williamson RC, Jiao LR (2007) Correlation between preoperative biliary drainage, bile duct contamination, and postoperative outcomes for pancreatic surgery. Surgery 142:313-318. https://doi.org/10.1016/j.surg.2007.04.022

28. Ramacciato G, Nigri G, Petrucciani N, Pinna AD, Ravaioli M, Jovine E, Minni F, Grazi GL, Chirletti P, Tisone G, Napoli N, Boggi U (2016) Pancreatectomy with mesenteric and portal vein resection for borderline resectable pancreatic cancer: multicenter study of 406 patients. Ann Surg Oncol 23:2028-2037. https://doi. org/10.1245/s10434-016-5123-5

29. Nakao A, Yamada S, Fujii T, Tanaka H, Oshima K, Oshima Y, Iede K, Kobayashi H, Kimura Y, Kodera Y (2018) Gastric venous congestion and bleeding in association with total pancreatectomy. 
J Hepatobiliary Pancreat Sci 25(2):150-154. https://doi.org/10. 1002/jhbp. 523

30. Jovine E, Biolchini F, Cuzzocrea DE, Lazzari A, Martuzzi F, Selleri S, Lerro FM, Talarico F (2004) Spleen-preserving total pancreatectomy with conservation of the spleen vessels: operative technique and possible indications. Pancreas 28(2):207-210. https://doi.org/10.1097/00006676-200403000-00013

31. Kimura W, Tezuka K, Hirai I (2011) Surgical management of pancreatic neuroendocrine tumors. Surg Today 41:1332-1343. https://doi.org/10.1007/s00595-011-4547-6

32. Boggi U, Signori S, De Lio N, Perrone VG, Vistoli F, Belluomini M, Cappelli C, Amorese G, Mosca F (2013) Feasibility of robotic pancreaticoduodenectomy. Br J Surg 100:917-925. https://doi.org/ 10.1002/bjs. 9135

33. Assumpcao L, Cameron JL, Wolfgang CL, Edil B, Choti MA, Herman JM, Geschwind JF, Hong K, Georgiades C, Schulick RD, Pawlik TM (2008) Incidence and management of chyle leaks following pancreatic resection: a high volume single-center institutional experience. J Gastrointest Surg 12:1915-1923. https://doi. org/10.1007/s11605-008-0619-3

34. Bockhorn M, Uzunoglu FG, Adham M, Imrie C, Milicevic M, Sandberg AA, Asbun HJ, Bassi C, Büchler M, Charnley RM, Conlon K, Cruz LF, Dervenis C, Fingerhutt A, Friess H, Gouma DJ, Hartwig W, Lillemoe KD, Montorsi M, Neoptolemos JP, Shrikhande SV, Takaori K, Traverso W, Vashist YK, Vollmer C, Yeo CJ, Izbicki JR, International Study Group of Pancreatic Surgery (2014) Borderline resectable pancreatic cancer: a consensus statement by the International Study Group of Pancreatic Surgery (ISGPS). Surgery 155:977-988. https://doi.org/10.1016/j.surg. 2014.02.001

35. Dindo D, Demartines N, Clavien PA (2004) Classification of surgical complications: a new proposal with evaluation in a cohort of 6336 patients and results of a survey. Ann Surg 240:205-213

36. Slankamenac K, Graf R, Barkun J, Puhan MA, Clavien PA (2013) The comprehensive complication index: a novel continuous scale to measure surgical morbidity. Ann Surg 258:1-7. https://doi.org/ 10.1097/SLA.0b013e318296c732

37. Wente MN, Bassi C, Dervenis C, Fingerhut A, Gouma DJ, Izbicki JR, Neoptolemos JP, Padbury RT, Sarr MG, Traverso LW, Yeo CJ, Büchler MW (2007) Delayed gastric emptying (DGE) after pancreatic surgery: a suggested definition by the International Study Group of Pancreatic Surgery (ISGPS). Surgery 142:761-768. https://doi.org/10.1016/j.surg.2007.05.005

38. Wente MN, Veit JA, Bassi C, Dervenis C, Fingerhut A, Gouma DJ, Izbicki JR, Neoptolemos JP, Padbury RT, Sarr MG, Yeo CJ, Büchler MW (2007) Postpancreatectomy hemorrhage (PPH)an International Study Group of Pancreatic Surgery (ISGPS) definition. Surgery 142:20-25. https://doi.org/10.1016/j.surg. 2007.02.001

39. Bonnetain F, Bonsing B, Conroy T et al (2014) Guidelines for time-to-event end-point definitions in trials for pancreatic cancer. Results of the DATECAN initiative (Definition for the Assessment of Time-to-event End-points in CANcer trials). Eur J Cancer 50:2983-2993. https://doi.org/10.1016/j.ejca.2014.07. 011

40. Mikami DJ, Melvin WS, Murayama MJ, Murayama KM (2017) Impact of minimally invasive surgery on healthcare utilization, cost, and workplace absenteeism in patients with Incisional/Ventral Hernia (IVH). Surg Endosc 31:4412-4418. https://doi.org/10. 1007/s00464-017-5488-y

41. Krimphove MJ, Reese SW, Chen X, Marchese M, Pucheril D, Cone E, Chou W, Tully KH, Kibel AS, Urman RD, Chang SL, Kluth LA, Dasgupta P, Trinh QD (2021) Recovery from minimally invasive vs. open surgery in kidney cancer patients: Opioid use and workplace absenteeism. Investig Clin Urol 62:56-64. https://doi.org/10.4111/icu.20200194
42. Kauppila JH, Xie S, Johar A, Markar SR, Lagergren P (2017) Meta-analysis of health-related quality of life after minimally invasive versus open oesophagectomy for oesophageal cancer. $\mathrm{Br}$ J Surg 104:1131-1140. https://doi.org/10.1002/bjs.10577

43. Maas KW, Cuesta MA, van Berge Henegouwen MI, Roig J, Bonavina L, Rosman C, Gisbertz SS, Biere SS, van der Peet DL, Klinkenbijl JH, Hollmann MW, de Lange ES, Bonjer HJ (2015) Quality of life and late complications after minimally invasive compared to open esophagectomy: results of a randomized trial. World J Surg 39:1986-1993. https://doi.org/10.1007/ s00268-015-3100-y

44. Lamadé W, Friedrich C, Ulmer C, Basar T, Weiss H, Thon KP (2011) Impact of body image on patients' attitude towards conventional, minimal invasive, and natural orifice surgery. Langenbecks Arch Surg 396:331-336. https://doi.org/10.1007/ s00423-010-0669-3

45. Scarpa M, Erroi F, Ruffolo C, Mollica E, Polese L, Pozza G, Norberto L, D'Amico DF, Angriman I (2009) Minimally invasive surgery for colorectal cancer: quality of life, body image, cosmesis, and functional results. Surg Endosc 23:577-582. https://doi. org/10.1007/s00464-008-9884-1

46. Weng Y, Chen M, Gemenetzis G, Shi Y, Ying X, Deng X, Peng C, Jin J, Shen B (2020) Robotic-assisted versus open total pancreatectomy: a propensity score-matched study. Hepatobiliary Surg Nutr 9(6):759-770. https://doi.org/10.21037/hbsn.2020.03.19

47. Biffl WL, Spain DA, Reitsma AM, Minter RM, Upperman J, Wilson M, Adams R, Goldman EB, Angelos P, Krummel T, Greenfield LJ, Society of University Surgeons Surgical Innovations Project Team (2008) Responsible development and application of surgical innovations: a position statement of the Society of University Surgeons. J Am Coll Surg. 206:1204-1209. https:// doi.org/10.1016/j.jamcollsurg.2008.02.011

48. McCulloch P, Altman DG, Campbell WB et al (2009) No surgical innovation without evaluation: the IDEAL recommendations. Lancet 374:1105-1112. https://doi.org/10.1016/S0140-6736(09) 61116-8

49. Tsiouris A, Cogan CM, Velanovich V (2011) Distal pancreatectomy with or without splenectomy: comparison of postoperative outcomes and surrogates of splenic function. HPB 13:738-744. https://doi.org/10.1111/j.1477-2574.2011.00369.x

50. Buzelé R, Barbier L, Sauvanet A, Fantin B (2016) Medical complications following splenectomy. J Visc Surg 153:277-286. https://doi.org/10.1016/j.jviscsurg.2016.04.013

51. Sinwar PD (2014) Overwhelming post splenectomy infection syndrome-review study. Int J Surg 12:1314-1316. https://doi.org/ 10.1016/j.ijsu.2014.11.005

52. Collard M, Marchese T, Guedj N, Cauchy F, Chassaing C, Ronot M, Dokmak S, Soubrane O, Sauvanet A (2019) Is routine splenectomy justified for all left-sided pancreatic cancers? Histological reappraisal of splenic hilar lymphadenectomy. Ann Surg Oncol 26:1071-1078. https://doi.org/10.1245/s10434-018-07123-8

53. Kim SH, Kang CM, Satoi S, Sho M, Nakamura Y, Lee WJ (2013) Proposal for splenectomy-omitting radical distal pancreatectomy in well-selected left-sided pancreatic cancer: multicenter survey study. J Hepatobiliary Pancreat Sci 20:375-381. https://doi.org/ 10.1007/s00534-012-0549-z

54. Schwarz RE, Harrison LE, Conlon KC, Klimstra DS, Brennan MF (1999) The impact of splenectomy on outcomes after resection of pancreatic adenocarcinoma. J Am Coll Surg 188:516-521. https:// doi.org/10.1016/s1072-7515(99)00041-1

55. Griffith JP, Sue-Ling HM, Martin I, Dixon MF, McMahon MJ, Axon AT, Johnston D (1995) Preservation of the spleen improves survival after radical surgery for gastric cancer. Gut 36:684-690. https://doi.org/10.1136/gut.36.5.684

56. Davis CJ, Ilstrup DM, Pemberton JH (1988) Influence of splenectomy on survival rate of patients with colorectal cancer. Am J 
Surg 1988(155):173-179. https://doi.org/10.1016/s0002-9610(88) 80276-9

57. Higashijima J, Shimada M, Chikakiyo M, Miyatani T, Yoshikawa K, Nishioka M, Iwata T, Kurita N (2009) Effect of splenectomy on antitumor immune system in mice. Anticancer Res 29:385-393

58. Imai S, Nio Y, Shiraishi T, Tsubono M, Morimoto H, Tseng CC, Kawabata K, Masai Y, Tobe T (1991) Effects of splenectomy on pulmonary metastasis and growth of SC42 carcinoma transplanted into mouse liver. J Surg Oncol 47:178-187. https://doi.org/10. 1002/jso.2930470309

59. Esposito A, Casetti L, De Pastena M, Ramera M, Montagnini G, Landoni L, Bassi C, Salvia R (2020) Robotic spleen-preserving distal pancreatectomy: the Verona experience. Updates Surg. https://doi.org/10.1007/s13304-020-00731-8

60. Warshaw AL (1988) Conservation of the spleen with distal pancreatectomy. Arch Surg 123:550-553. https://doi.org/10.1001/ archsurg.1988.01400290032004

61. Mosca F, Giulianotti PC, Balestracci T, Boggi U, Giardino D, Di Candio G, Rossi G, Fornaciari G (1994) Preservation of the pylorus in duodenocephalopancreatectomy in pancreatic and periampullary carcinoma. Chir Ital 46:59-67

62. Boggi U, Del Chiaro M, Croce C, Vistoli F, Signori S, Moretto C, Amorese G, Mazzeo S, Cappelli C, Campani D, Mosca F (2009) Prognostic implications of tumor invasion or adhesion to peripancreatic vessels in resected pancreatic cancer. Surgery 146:869-881. https://doi.org/10.1016/j.surg.2009.04.029

63. Kauffmann EF, Napoli N, Menonna F, Vistoli F, Amorese G, Campani D, Pollina LE, Funel N, Cappelli C, Caramella D, Boggi U (2016) Robotic pancreatoduodenectomy with vascular resection. Langenbecks Arch Surg 401:1111-1122. https://doi.org/10. 1007/s00423-016-1499-8

64. Muttillo EM, Felli E, Pessaux P (2020) Cattell-Braasch maneuver in pancreatic surgery. No need of venous graft for vascular resection. J Surg Oncol 122:1612-1615. https://doi.org/10.1002/jso. 26180

65. Allan BJ, Novak SM, Hogg ME, Zeh HJ (2018) Robotic vascular resections during Whipple procedure. J Vis Surg 4:13. https://doi. org/10.21037/jovs.2017.12.15

66. Shyr BU, Chen SC, Shyr YM, Wang SE (2020) Surgical, survival, and oncological outcomes after vascular resection in robotic and open pancreaticoduodenectomy. Surg Endosc 34:377-383. https:// doi.org/10.1007/s00464-019-06779-x

67. Kendrick ML, Sclabas GM (2011) Major venous resection during total laparoscopic pancreaticoduodenectomy. HPB 13:454-458. https://doi.org/10.1111/j.1477-2574.2011.00323.x
68. Khatkov IE, Izrailov RE, Khisamov AA, Tyutyunnik PS, Fingerhut A (2017) Superior mesenteric-portal vein resection during laparoscopic pancreatoduodenectomy. Surg Endosc 31:1488-1495. https://doi.org/10.1007/s00464-016-5115-3

69. Maker AV, Sheikh R, Bhagia V, Diabetes Control and Complications Trial (DCCT) Research Group (2017) Perioperative management of endocrine insufficiency after total pancreatectomy for neoplasia. Langenbecks Arch Surg 402:873-883. https://doi.org/ 10.1007/s00423-017-1603-8.39

70. de Rooij T, van Hilst J, Vogel JA, van Santvoort HC, de Boer MT, Boerma D, van den Boezem PB, Bonsing BA, Bosscha K, Coene PP, Daams F, van Dam RM, Dijkgraaf MG, van Eijck CH, Festen S, Gerhards MF, Groot Koerkamp B, Hagendoorn J, van der Harst E, de Hingh IH, Dejong CH, Kazemier G, Klaase J, de Kleine RH, van Laarhoven CJ, Lips DJ, Luyer MD, Molenaar IQ, Nieuwenhuijs VB, Patijn GA, Roos D, Scheepers JJ, van der Schelling GP, Steenvoorde P, Swijnenburg RJ, Wijsman JH, Abu Hilal M, Busch OR, Besselink MG, Dutch Pancreatic Cancer Group (2017) Minimally invasive versus open distal pancreatectomy (LEOPARD): study protocol for a randomized controlled trial. Trials 18:166. https://doi.org/10.1186/s13063-017-1892-9

71. Galvani CA, Rilo HR, Samamé J, Gruessner RW (2013) First fully robotic total pancreatectomy combined with islet autotransplantation for the treatment of chronic pancreatitis: a case report. Pancreas 42:1188-1189. https://doi.org/10.1097/MPA.0b013e3182 $7 \mathrm{fe} 875$

72. Marquez S, Marquez TT, Ikramuddin S, Kandaswamy R, Antanavicuis G, Freeman ML, Hering BJ, Sutherland DE (2010) Laparoscopic and da Vinci robot-assisted total pancreaticoduodenectomy and intraportal islet autotransplantation: case report of a definitive minimally invasive treatment of chronic pancreatitis. Pancreas 39:1109-1111. https://doi.org/10.1097/MPA.0b013e3181df262c

73. Asbun HJ, Stauffer JA (2012) Laparoscopic vs open pancreaticoduodenectomy: overall outcomes and severity of complications using the accordion severity grading system. J Am Coll Surg 215:810-819. https://doi.org/10.1016/j.jamcollsurg.2012.08.006

Publisher's Note Springer Nature remains neutral with regard to jurisdictional claims in published maps and institutional affiliations. 